\title{
Distribution and Zonation of Mangroves in the Northern Part of the Negombo Lagoon (Sri Lanka)
}

\author{
M. L. Pinto \\ Department of Biology, De La Salle University, 2401 Taft Avenuie, Manila, Philippines. \\ (Date of receipt : 10 August 1981) \\ (Date of acceptance : 13 December 1982)
}

\begin{abstract}
The species diversity in the mangal of Negombo is remarkable. The overall scaled Simpson diversity index was 0.424 . Some islets were completely covered by Acanthus ilicifolius, while the others had a Rhizophora border and a mixed vegetation, dominated either by Avicennia marina or Bruguicra gymnorhiza. The vegetation pattern and the elevation suggest that mud flat is the precursor of the mangal. A. ilicifolius may be the early colonizer in boggy soils. A. marina occurred on firm soils. The presence of a Rhizophora border on the shore may be due to its morphological adaptations in resisting water currents with the help of prop roots.
\end{abstract}

Daily variation in the tidal level was too small (neap tides $2 \mathrm{~cm}$ and spring tides $18.4 \mathrm{~cm}$ ) to show a spectacular pattern in zonation. Soils from the mud flat, Rhizophora border and the interior of the islets showed the characteristic features of each rogion with respect to $\mathrm{pH}$, organic matter, particle size, $\mathrm{Na}+$ and $\mathrm{Ca}++$ concentrations. $\mathrm{Ca}++$ content was high in the mud flat but $\mathrm{Na}+$ was the predominant exchangeble cation in the mangrove soil.

Measurements of diameters and heights of plants showed that B. gymnorhiza and C. taga! are in their early stages of growth while $L$. racemosa has been overexploited.

\section{Introduction}

Mangroves appear to be an evil smelling, treacherous bog, infested with mosquitoes. Recently the value of mangroves has been realized by many scientists. They are the breeding grounds of crustacean and fish larvae, and they constantly supply the coastal waters with nutrients. Mangroves in Sri Lanka in general, and those of Negombo in particular, are fast disappearing due to population expansion and industrial pressure. Aruchelvam ${ }^{2}$ estimated the extent of mangroves in Sri Lanka. to be $8,000-10,000$ acres. In the eighties, the mangrove area may be less than 8,000 acres. Other than taxonomic studies and general descriptions, very little work has been done on the mangrove communities of Sri Lanka.

This paper is an attempt to study the distribution pattern and zonation of mangroves in selected islets in the northern part of the Negombo lagoon in relation to some environmental factors. 


\section{The Study Area}

This study was carried out in selected mangrove islets (Figure 1) in the Negombo lagoon latitude $7^{\circ} 11^{\prime} \mathrm{N}$, and longitude $79^{\circ} 50^{\prime} \mathrm{E}$, in the west coast of Sri Lanka. The lagoon opens to the sea from the northern end while the southern end, receives fresh water from Ja-Ela, Dandugam Oya and a Dutch canal. The three islets, Islet I (Kakaduwa) Islet 2 (Mandagas alamba) and Islet 3 (Kadolnallala) had areas of 2.24 ha, 5.88 ha and 2.92 ha, respectively. Between Islet 1 and Islet 3 was the mudflat which was submerged only during the high tides.

\section{Materials And Methods}

After making superficial observations on the vegetation around the lagoon, it was thought best to select the uninhabited islands for this study. The vegetation pattern was constructed by chain surveying. In order to study the zonation in islet 1, a transect was chosen across the middle of the islet and different plant species occurring in $2 \times 2 \mathrm{~m}^{2}$ quadrats along the transect was noted as well as their heights and diameters at ground level.

Soil samples were collected from the mudflat, Rhizophora border and the interior of islet 1 and the salinity was determined by titration, organic matter by Walkly and Black method ${ }^{4} \mathrm{Ca}$ and $\mathrm{Mg}$ by titration with $0.005 \mathrm{M}$ EDTA and $\mathrm{Na}$ and $\mathrm{K}$ using a calibrated flame Photometer.

Tidal levels were measured daily at low tide and high tide for one year and the cumulative percentages in the water level for each month was calculated. From these results, the $50 \%$ submergence for each month was constructed as shown by the broken line in Figure 2 .

This study was made from December 1976 to December 1977.

\section{Results}

Figure 1 gives the general distribution pattern of the vegetation in the northern part of the lagoon. Figure 3 gives the distribution of mangroves in detail in 3 selected islets. Table 1 shows the approximate areas of plant cover due to predominant vegetation type. Zonation of different plant species along a transect in islet 1 is shown in Figure $4 \mathrm{~A}$ and their heigh ts and diameters given in Table 2. Some edaphic factors were also measured from the different zones in the environment with the view to correlate with zonation and the results are given in Table 3. 


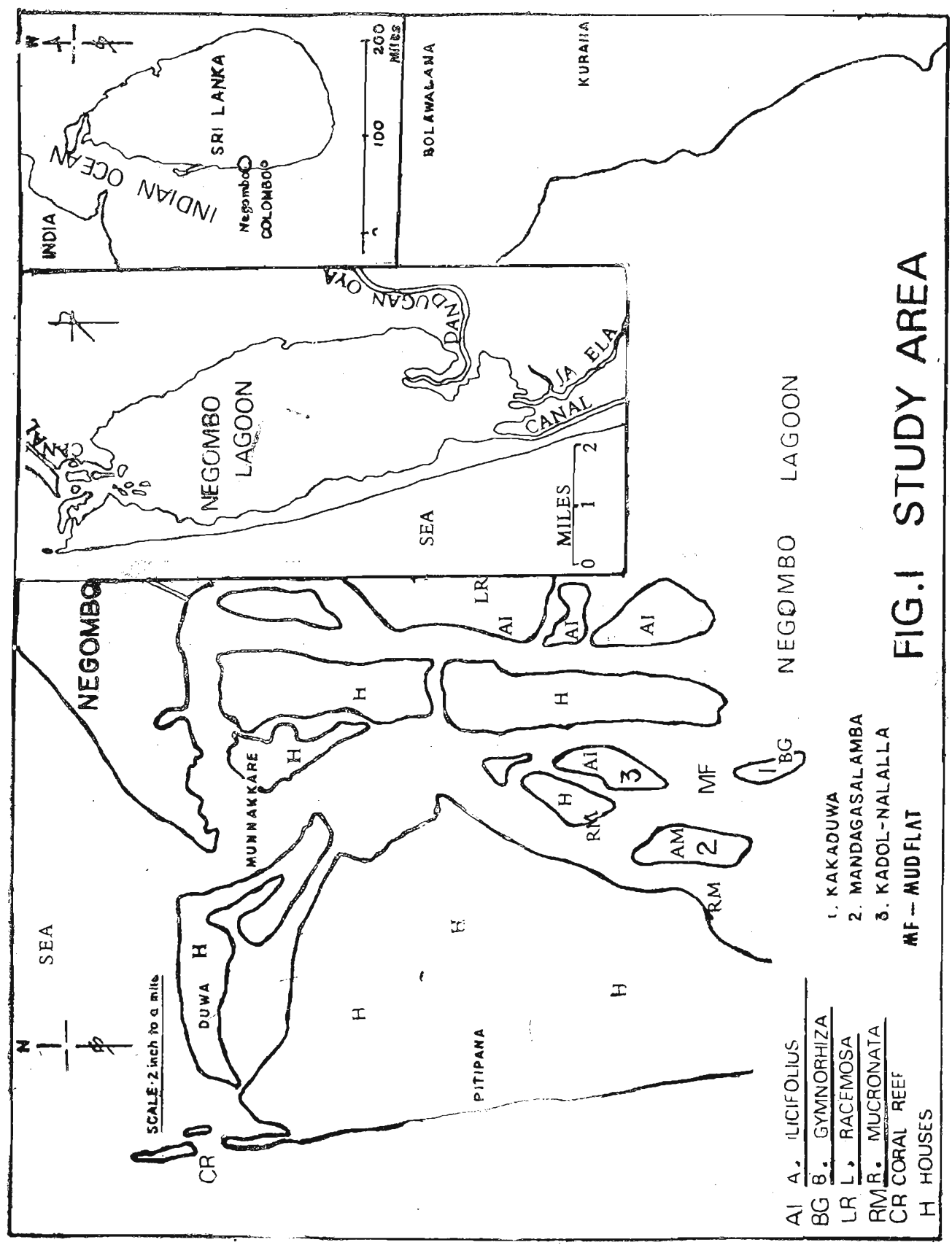




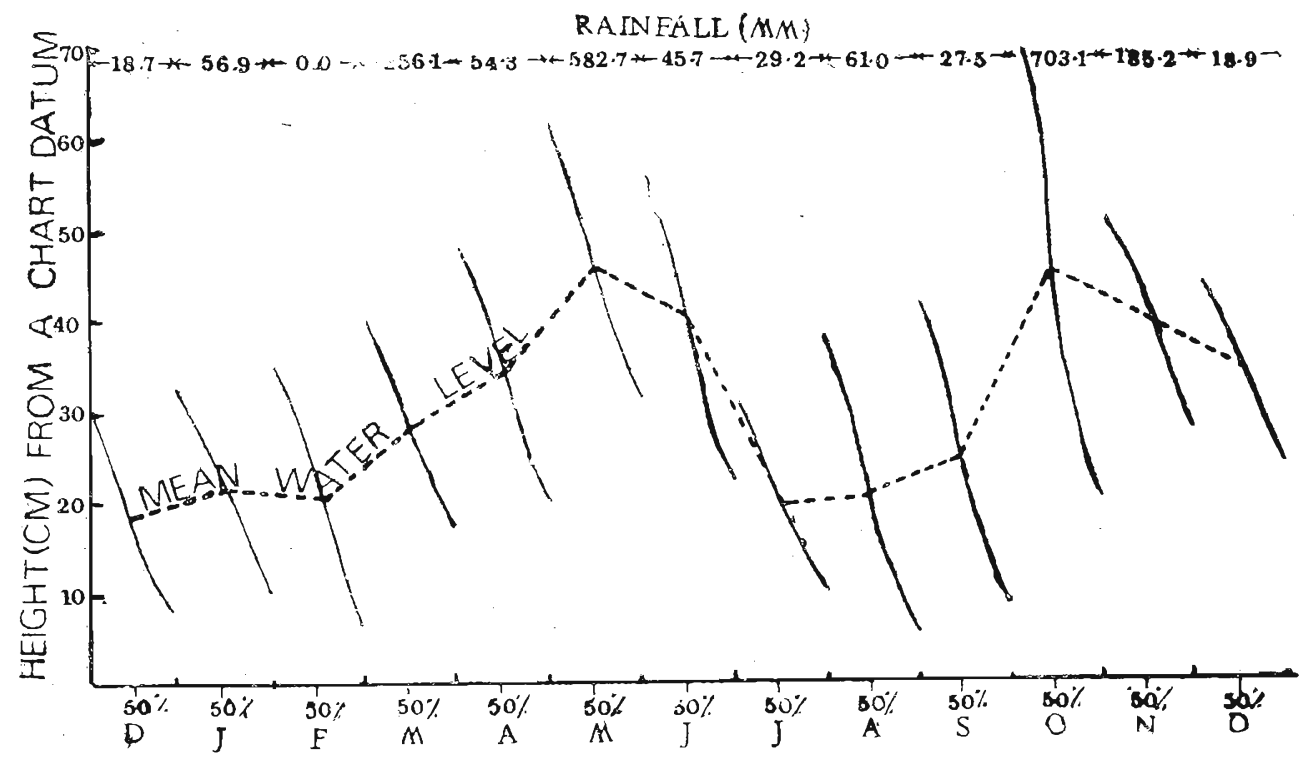

\section{PERCENTAGE CLIVIULATIVE FREQUENCIES}

Figure 2. The rarge of tidal fluctuations for each month and the mean water level of the Negombo lagoon. Percentage cumulative frequencies were obtained from the daily measurements of high tide and low tide levels. (1977).

TABLE 1. The approximate area covered by the predominant vegetation types in the islets.

\begin{tabular}{|c|c|c|c|}
\hline Vegetation type & $\underset{\text { (Ha) }}{\text { ISLET } 1}$ & $\begin{array}{c}\text { ISLET } 2 \\
(\mathrm{Ha})\end{array}$ & $\underset{\text { (Ha) }}{\text { ISLET } 3}$ \\
\hline Rhizophora, around the islet & 0.019 & 0.366 & - \\
\hline A. ilicifolius & 0.390 & 0.030 & 1.810 \\
\hline L. racemosa & 0.145 & - & - \\
\hline E. aggalocha & 0.098 & - & 0.010 \\
\hline Grasses and sedges & 0.003 & 0.032 & - \\
\hline B. gymnorhiza & 1.678 & 2.206 & - \\
\hline A. marina & 0.001 & 0.690 & 0.060 \\
\hline \multicolumn{4}{|l|}{ L. racemosa, gymnorhiza } \\
\hline A. marina and C. tagal & - & 2.554 & - \\
\hline Rhizpohora, Bruguiera and & & 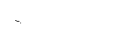 & \\
\hline Acanthus ilicifolius & - & - & 0.500 \\
\hline Aegiceras and Acanthus & - & - & 0.390 \\
\hline C. inerme & - & - & 0.080 \\
\hline Derris sp. with Acanthus & - & - & 0.070 \\
\hline
\end{tabular}



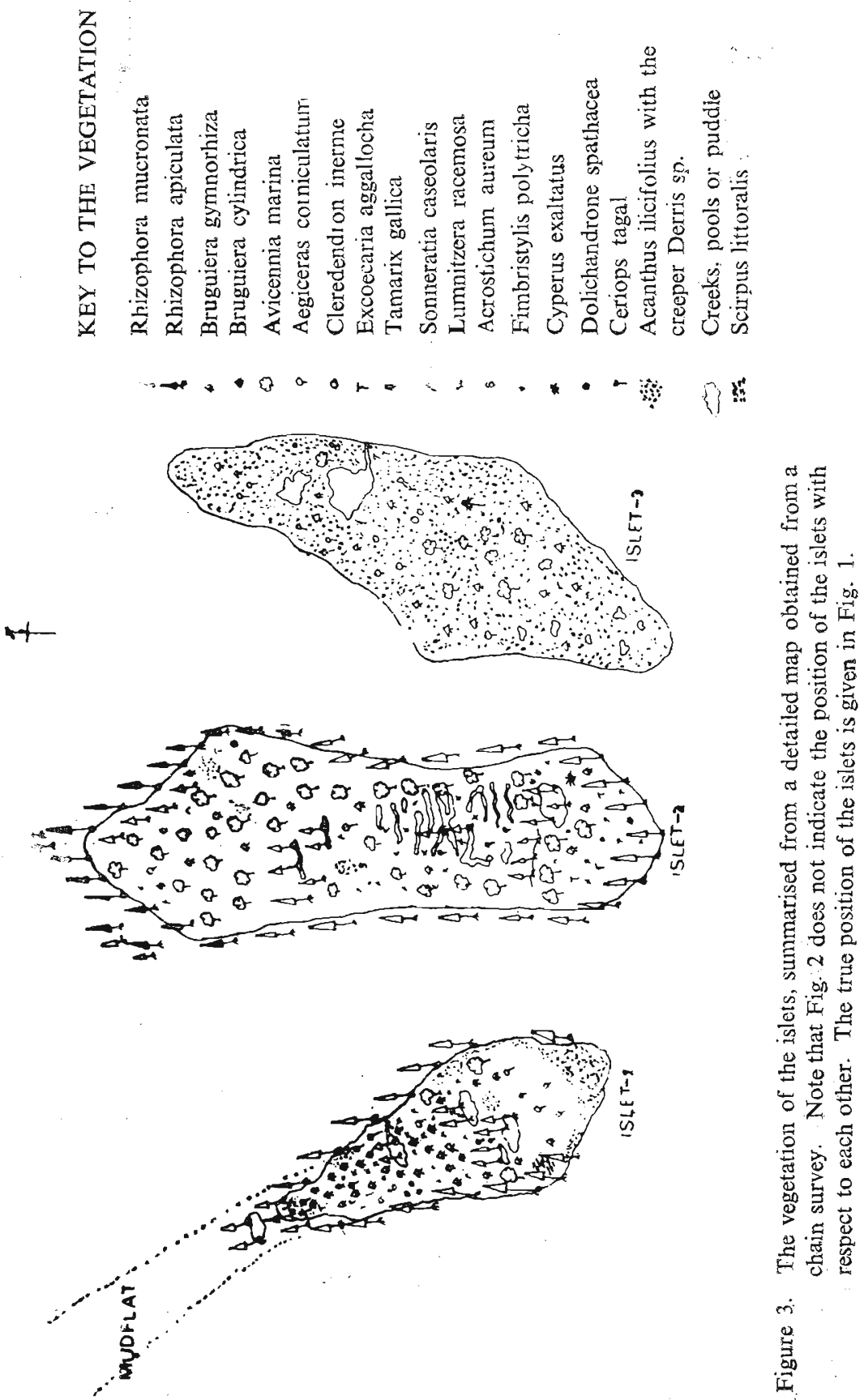


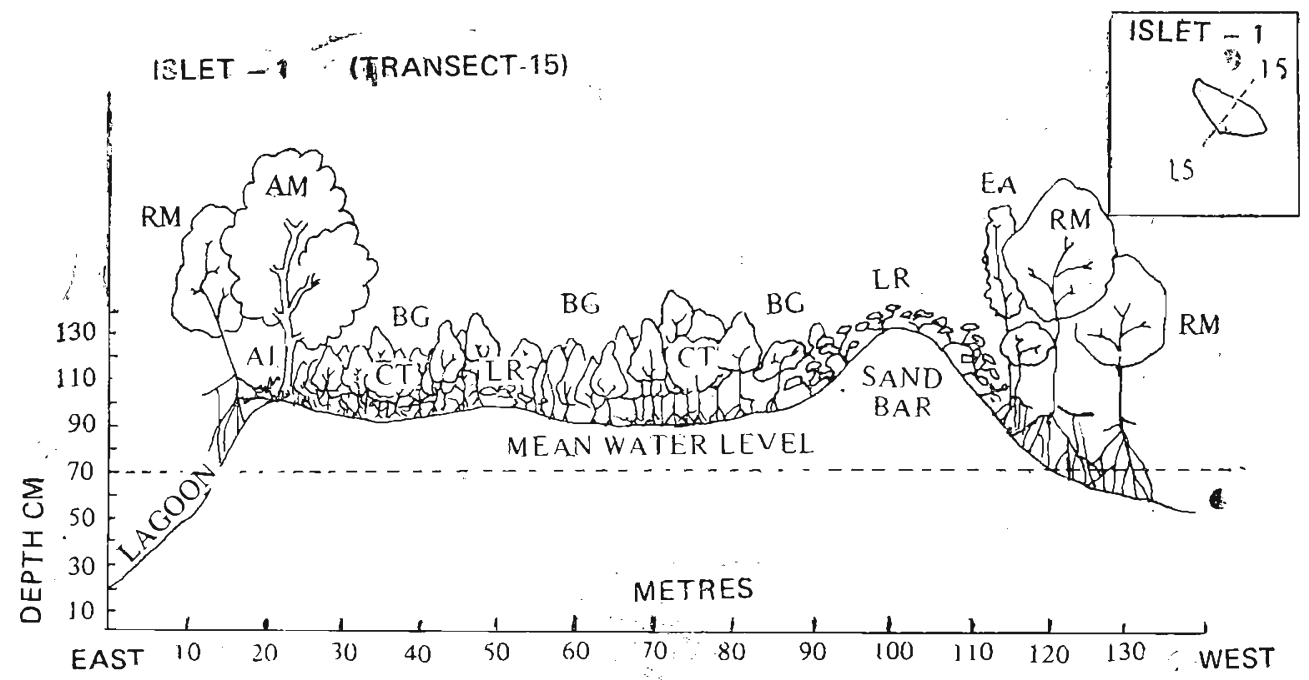

Figure 4A The elevation and plant zonation along transect 15 in islet 1 . Heights of the plants do not correspond to the scale in the ordinate.

BG B gymnorhiza
A! A. ilicifolius
RM R. mucronata
EA E. aggallocha

CT C tagal

LR L. racemosa

AM $A$. marina

EA E. aggallocha

TABLE 2. The heights and diameters of plants across the 25 th transect in islet 1 .

HEIGHTS IN METRES

\begin{tabular}{lccccccccc}
\hline \multicolumn{1}{c}{ class } & $0-8$ & $8-16$ & $16-24$ & $24-32$ & $32-40$ & $40-48$ & $48-56$ & $56-64$ & $64-72$ \\
\hline species & 75 & 76 & 18 & - & 1 & 4 & 5 & 1 & - \\
$\begin{array}{l}\text { B. gymnorhiza } \\
\text { R. mucronata }\end{array}$ & 8 & 1 & - & 1 & 1 & 5 & 5 & 3 & 1 \\
$\begin{array}{l}\text { C. tagal } \\
\text { L.racemosa }\end{array}$ & 23 & 7 & 2 & - & - & - & - & - & - \\
\hline
\end{tabular}

DIAMETER IN CM

\begin{tabular}{lrrrrrrrrr}
\hline \multicolumn{1}{c}{ class } & $0-2$ & $2-4$ & $4-6$ & $6-8$ & $8-10$ & $10-12$ & $12-14$ & $14-16$ & $16-18$ \\
\hline species & 165 & 30 & 1 & - & - & - & - & - & - \\
$\begin{array}{l}\text { B. gymnorhiza } \\
\text { R. mucronatd }\end{array}$ & 13 & 3 & 8 & - & - & - & - & - & - \\
C. tagal & 19 & 3 & - & - & - & - & - & - & - \\
L. racemosa & - & 4 & 9 & 9 & 2 & 2 & - & 3 & 1 \\
\hline
\end{tabular}




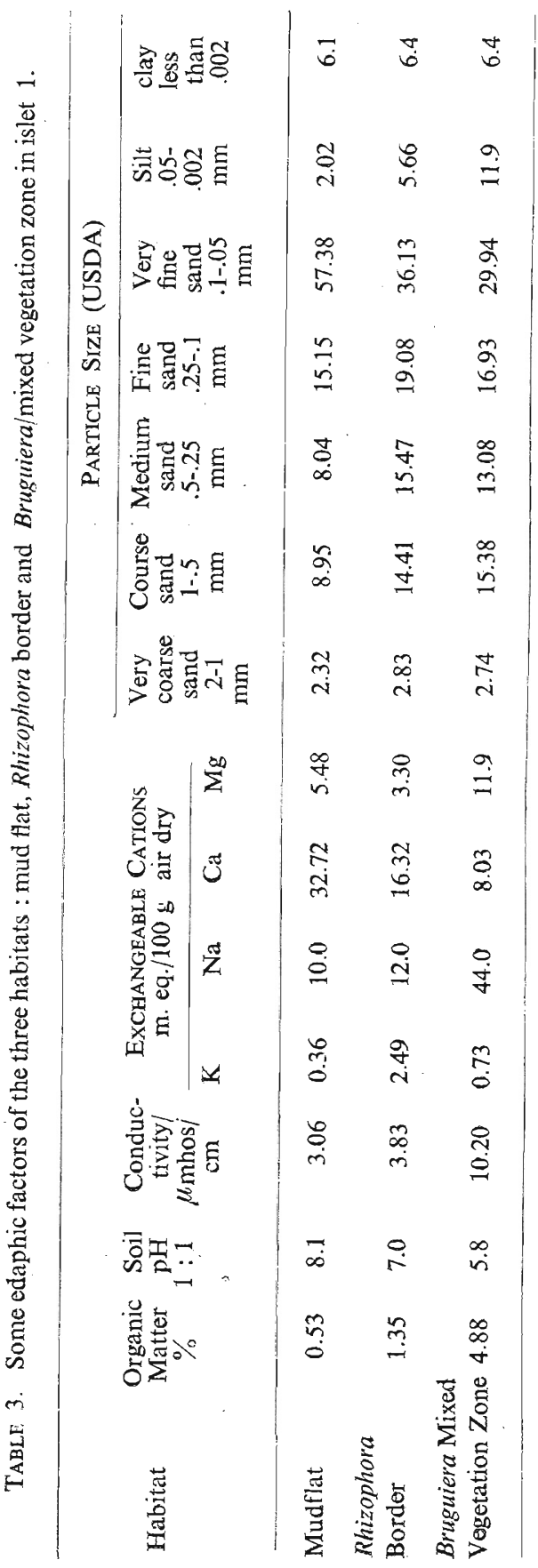




\section{Discussion}

Out of the 28 mangrove species listed for Sri Lanka 14 species were found in these islets. As these islets were not connected with the mainland, the entire community formed the mangal, with no hinterland vegetation. Compared to the other mangrove patches along the west coast of Sri Lanka, the mangroves of Negombo show high diversity in species composition. In Waikkal north of Negombo Nypa fruticans is abundant. Xylocarpus granatum and Heritiera littoralis occur in the mangroves of Chilaw. Mundel-Puttalam area is dominated by Tamarix gallica, Acrostichum aureum, Excoecaria agalocha, Avicennia marina together with the sait marsh vegetation. Aruwakkalu mangal has tall Rhizophoras and A. marina dominates the dry zone mangroves. In the south, Nypa fruticans though present is fast disappearing due to cocount fiber industry. Compared to the sparse vegetation elsewhere, the rich vegetation in the mangrove islets is clearly shown in Figure 3 and Table 1. Scaled Simpson index values showed a high degree of diversity along the shores of islet I. (Figure 4B)

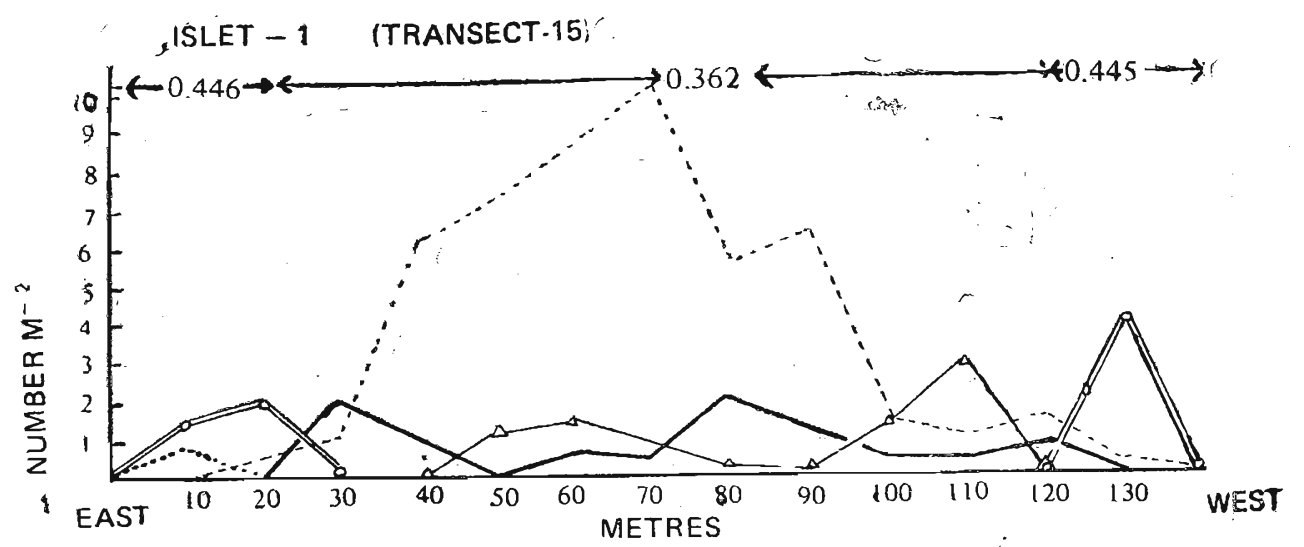

Figure 4B Population densities of different species along the transect. Scaled Simpson diversity indices (1-D) for the shores and the middle of the islet are also given. Overall density index for the transect is 0.424

\begin{tabular}{lll}
$\ldots . .$. B. gymnorhiza & \multicolumn{1}{c}{ C. tagal } \\
$\ldots . .$. A. ilicifolius & $\Delta-\Delta$ L. racemosa \\
\hline R. mucronata & $-\infty$ & A. marina
\end{tabular}




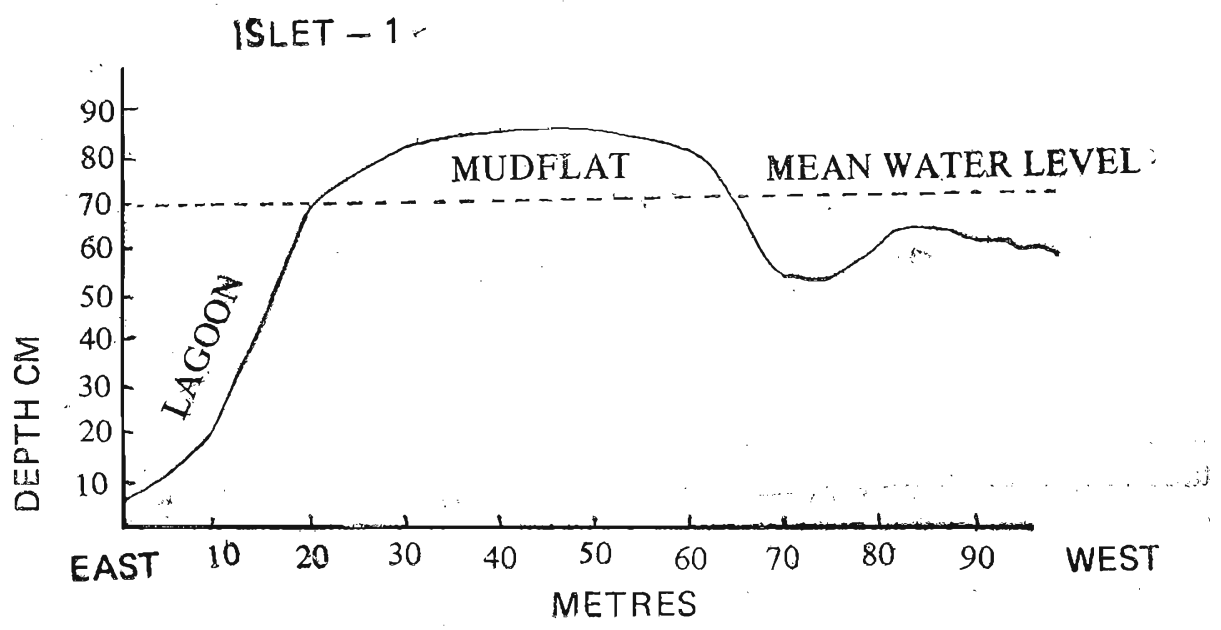

Figure $4 \mathrm{C}$ Elevation of the mudflat.

Zonation within the mangrove community has been fully established by early workers. Watson ${ }^{19}$ recognized 5 zones in the Malayan mangroves on the basis of tidal inundation. De Haan $^{5}$ pastulated 6 zones and suggested the soil salinity to be a major factor and tide to be a subsidiary factor. Walter and Steiner ${ }^{18}$ Macnae and $\mathrm{Kalk}^{13}$ and Macnae ${ }^{12}$ working on the African mangroves realized 6 zones not on the basis of physical factors but on the basis of dominating species. Abeywickrama's generalization of 3 mangrove zones, namely Rhizophora or Avicennia zone, mixed vegetation zone and the littoral woodland vegetation, holds good for these islets except for the woodland vegetation. Presence of a Rhizophora border instead of an Avicennia border in islet I and islet 2 (Figure 3) may be due to the depth and slope as suggested ${ }^{1},{ }^{11}$ as well as due to the lack of sandy soil and poor aeration. ${ }^{18}$

Figure 4 shows clearly the high population density of $R$. mucronata along the border and the high density of $B$. gymnorhiza towards the interior. Lumnitzera racemosa prefers elevated areas as indicated in the same figure. From table 2 it is clear that most of the B. gymnorhiza and C. tagal plants have small diameters and are short. The fact that $L$. racemosa are short and bushy with large diameters indicate that they have been overexploited. The heights of mangroves observed in these islets are far short compared to the mangroves of Puerto Rico ${ }^{8}$, Malaysia $^{6}$ and India. ${ }^{10}$ It should be noted that variation in vegetation pattern occurs within the islet and a single transect is insufficient for any generalization. But the occurrence of a Rhizophora border is true for any transect taken from islet 1 or islet 2.

F-7 18510 
On evaluating the reasons for zonation, the approach has to be one of reductio ad absurdum. Since zonation is not so spectacular the necessary environmental factors could be accounted for, by their absence. In the lagoon the mean spring tide fluctuation was $0.184 \mathrm{~m}$ and the mean neap tide fluctuation was $0.020 \mathrm{~m}$. From Figure 2 it is clear that seasonal variation in water level due to rains become an important factor than the daily tidal variation. Tide appears to be an important factor for zonation, since zonation is clear in areas where tidal fluctuation is high. For instance $8 \mathrm{~m}$ tidal variation was recorded for well zoned mangrove areas of Australia, $5 \mathrm{~m}$ for Malaysia and 3.5 for Mozambique. ${ }^{12}$ The soil salinity did not show much variation at different stations in the same islet as it showed with different seasons. The presence of Rhizophoras along the shore may be due to their morphological adaptation to withstand water currents by their proproots. However the Bruguiera mixed vegetation in the interior of the islets showed high precentage of organic matter, high $\mathrm{Na}$ content and low $\mathrm{pH}$ compared to the Rhizophora border (Table 3).

The vegetation pattern in the islets and the mud flat shows some trends in the succession of the mangrove communities. The mud flat as a precursor of saltmarsh communities in temperate countries has been fully established. $7,9,15$ From the low elevation of the mudflat (Figure 4) compared to the elevation of islet 1 , it is possible to conclude that mud flat is the precursor of mangrove communities in this locality. Islet 3 is often submerged with poorly consolidated soil and dominated by A. ilicifolius. This vegetation type disappears gradually with the elevation as seen from Table 1. Islet 2 as well as islet 1 are completely submerged during the rainy season in May and October. Islet 2 has a Rhizophora border of tall trees (Height $7 \pm 2 \mathrm{~m}$ and diameter $12 \pm 5 \mathrm{~cm}$ ) compared to the Rhizophora border of islet 1 (Height $5 \pm 2 \mathrm{~m}$ and diameter $5 \pm 3 \mathrm{~cm}$ ). A. marina formed the predominant vegetation in islet 2 with different heights as trees $(4-7 \mathrm{~m})$, shrubs $(2-4 \mathrm{~m}$ ) and saplings (less than $2 \mathrm{~m}$ ) similar to the observations of Bruce et al (1975) on A. marina in Australia. From the vegetation type, elevation and the size of the plants the chronology of colonization may have been in the following series.

$\begin{array}{rlll}\text { MUD FLAT } \longrightarrow \rightarrow & \text { ISLET } 3-\rightarrow & \text { ISLET } 1 \cdots & \text { ISLET } 2 \\ & \text { A. ilicifolizis } & \text { Rhizophora } & \text { Rhizophora border } \\ & \text { type of } & \text { border with } & \text { with } \text { A. marina mixed, } \\ & \text { vegetation } & \text { B.gymnorhiza } & \text { vegetation }\end{array}$

After the primary community established itself on the mud flat, the prop roots, knee roots and pneumatophores may have accelerated sedimentation. $3: 16,17$

In the same locality were seen pure strands of Rhizophora seedlings emerging from mud flats. These were not a result of natural succession but planted by the fishermen with the view of reclaiming land and harvesting timber. 
With the changes in the soil structure and elevation of the mud flat and the mangal proper, not only the vegetation but faunation too has shown marked differences. While Macrophtalums depressus and a few other Ocypodid crabs occurred on the mud flat, the mangal was dominated by the Sesarmid crabs as exemplified by Chiromantes darwinensis, C.indiarum, C. bidens, Neoepisesarma versicolor, Neosermatium smithi and Neosermatium malbaricum ${ }^{14}$. Due to the absence of a vegetation on the mud flat the fauna generally associated with the mangrove leaves, stems and roots were not found in the mud flat.

\section{References}

1. Abeywickrama B. A. (1960): The vegetation of the lowlands of Ceylon in relation to soils and vegetation. Proceedings of the Abidjan Symposium UNESCO pp $87-92$

2. Aruchelvam K. (1968) The mangroves The Ceylon Forestor 8, (3 \& 4): 59.92

3. BrRD E.C.F. (1972) Mangroves and coastal morphology in Cairns Bay, North Queensland Journal af Tropical geography 35: 11-16

4. Black C. A., Evans D. D., White J.L., Enswinger L.E. \& Clark F.E. (1965) Methods of Soil analysis Part II : Chemical and microbiological properties. pp. 999 - 1009 American Society of Agronomy.

5. DE HANN J.H. (1931) Het een en ander over de Tijlatjap'sche Vloedbosschen. Tectona 24: 39 - 76 (English summary)

6. Durrant C. C. L. (1941) The growth of mangrove species in Malaya. Malayan Forest. $10: 3-5$

7. Ginsburg R. N. \& Lowenstam H. A. (1958) The influence of marine bottom communities on the depositional environment of sediments. J. Geol $66: 310-318$.

8. Holdridge L.R. (1947) Some notes on the mangrove swamps of Puerto Rico. Caribh. Forest 1, (4): $19-2$;

9. KAMPS L.F. (1962) Mud distribution and land reclamation in eastern Wadden shallows. Rijkswat St. Commun. $4: 1-73$

10. Krishnamurthy K. \& Jayaseelan M. J. P. (1980) The impact of the Pichavaran mangrove ecosystem upon coastal natural resources. A case study from southern India.

Paper presented at the Asian Symposium on mangrove environment, UNESCO Malaysia.

11. KUGATHASAN K. S. (1969) Mangrove vegetation of the lagoon : Hydrobiological survey of the Thondaimannar lagoon. Bulletin 7. Northern Plovince Science Teachers' Association.

12. MACNAE W (1968) A general account of the fauna and flora of mangrove swamps. Advances. in Marine Biology $6: 73-270$.

13. MaCNAE W \& KaLK M. (1962) The ecology of the mangrove swamps of Inhaca, Mozambique J. Ecol. 50 : $19-34$

14. Pinto M.I. (1980) Some ecological aspects of a population of mangroves crabs occurring within the islets of Negombo lagoon, Sri Lanka. Paper presented at the Asian symposium on mangrove environments. UNESCO, Malaysia.

15. RANWELL D.S. (1972) Ecology of salt marshes and sand dunes. Chapman \& Hall.

16. Sholl D. W. (1968) Mangrove swamps : Geology and Sedimentology Encyclopedia of Geomorphology. Edited by R. W. Fairbridge PP $683-688$

17. Тном B. G. (1967) Mangrove ecology and deltaic geomorphology : Tabasco, Mexico. J. Ecol. $55: 301-343$.

18. Walter H \& M. Steiner (1936) Die Okologie der Ost-Afrikanishen Mangroven. Z.Bot. $30: 65-193$

19. Watson J. G. (1928) : Mangrove forests of the Malay Peninsula. Malay forest Rec. 6 pp 275 